\title{
The effect of hydrolyzate on amino acid levels in Nile tilapia (Oreochromis niloticus)
}

\author{
${ }^{1, *}$ Nuryanto, ${ }^{2}$ Chasanah, E., ${ }^{1}$ Afifah, D.N., ${ }^{1}$ Sulchan, M., ${ }^{2}$ Martosuyono, P. and \\ ${ }^{1}$ Ihsani, K. \\ ${ }^{I}$ Department of Nutrition Science, Faculty of Medicine, Diponegoro University; Jl. Prof. Soedarto \\ $\mathrm{SH}$, Tembalang Semarang Indonesia \\ ${ }^{2}$ Research and Development Center for Marine and Fisheries Product Processing and Biotechnology, Jl. KS \\ Tubun, Petamburan 6, Slipi, Jakarta, Indonesia
}

\begin{abstract}
Article history:
Received: 8 February 2021

Received in revised form: 16

March 2021

Accepted: 19 March 2021

Available Online: 22 August 2021
\end{abstract}

Keywords:

Amino Acid,

$\mathrm{FPH}$,

Hydrolyzate,

Nile tilapia

DOI:

https://doi.org/10.26656/fr.2017.5(S3).003

\begin{abstract}
Fish is one of the most important foods in the human diet because of its high nutritional quality. One of the potential local foodstuffs in Grobogan is Nile tilapia (Oreochromis niloticus). Nile tilapia has a high nutrient content, especially protein. To obtain better benefits from fish protein, it can be processed into fish protein hydrolysate (FPH) products. Fish protein hydrolysates (FPH) which contain a mixture of small protein or peptides and free amino acids are beneficial for children diet, in preventing and combating malnutrition problems through readily absorbed essential amino acids. This study aimed to analyze the amino acid profile of Nile tilapia and fish protein hydrolysate (FPH) from Nile tilapia. The treatments included processing Nile tilapia into hydrolysate and analyse amino acids of Nile tilapia before and after hydrolysate. The process of making FPH uses a local microbial protease enzyme from Bacillus licheniformis. Amino acids composition was analysed using an internal method developed by Saraswanti Indo Genetech laboratory (185-17/MU/SMM-SIG, UPLC). Data were analysed using the paired t-test statistical test. The results showed there were significant differences in the rate of all amino acid profiles $(p<0.05)$, except L-Aspartic Acid, L-Tyrosine and L-Histidine $(p>0.05)$. From the research, it can be concluded hydrolysate processing has an effect on the increase of Lglutamic acid and L-lysine amino acid.
\end{abstract}

\section{Introduction}

One of the foods that were abundant in Indonesia and have the potential to prevent growth stunting is fish. Fish is well known as an aquatic animal that can serve as an excellent source of nutrition as they contain highquality proteins (FAO, 2018; Magouz et al., 2021). Fish is a great source of high-quality protein, low fat, and provides essential micronutrients for health and growth. In addition to its excellent nutritional content, fish is a highly perishable product. Therefore, a technological breakthrough was needed to utilize fish resources to increase the added value of its products, by making fish protein hydrolysate (FPH).

Fish protein hydrolysate is a fish protein hydrolysis product that contains high protein, complete amino acids, and is easy to digest, to ensure it can be an alternative to meet protein sufficiency and has the potential to be used as a protein fortification material in food products. In the form of hydrolysate, fish protein will be broken down into short proteins or peptides and free amino acids which are more readily absorbed and increases the availability of amino acids in plasma blood compared to their native protein. This will be useful if given to children who have indications of malnutrition such as stunting. Drying the hydrolysate quickly will ensure its quality. It also maintained and has high nutritional composition. The process of making FPH used biologically by a local microbial protease enzyme from Bacillus licheniformis (Chasanah et al., 2018). The production process uses local protease from the bacterium Bacillus licheniformis, which produces a protein hydrolysate product that is free from annoying bitter or salty taste, in similar products using papain.

Grobogan is one of the places that has abundant local foodstuffs of freshwater fish, such as Nile tilapia (Oreochromis niloticus). Nile tilapia is one of the most cultivated fish, which at about $75 \%$. Nile tilapia has a 
high economic value and high nutritional content (Dawood et al., 2020). In Indonesia, malnutrition is one of the biggest nutritional problems. Indonesia's basic health research (RISKESDAS 2018) report that nutritional status of children under five in Indonesia is still quite high, the prevalence of underweight children at $17.7 \%$, consisting of $3.9 \%$ malnutrition and $13.8 \%$ undernutrition, and stunting prevalence of 30.8\% consists of $11.5 \%$ very short and $19.3 \%$ short (Ministry of Health Republic of Indonesia, 2018). One of the districts in Central Java with a high prevalence of stunting is Grobogan (37.6\%).

Protein needs are also closely related to the incidence of stunting (Uauy et al., 2016). Stunting children had lower serum concentrations in all nine essential amino acids. The research on toddlers in Malawi showed that 9 essential amino acids in the blood serum of stunted children are very low which results in repression of protein and fat synthesis by the mTORC1 gene which can inhibit cell growth (Semba et al., 2016). One of three children under five in Indonesia is stunted due to protein deficiency (UNICEF, 2013). Research conducted in Grobogan indicates that low intake of protein and zinc are positively related to stunting (Shokibi, 2015). The research in Africa shows stunted children have low levels of essential amino acids such as tryptophan and lysine from their diet (Nuss and Tanumihardjo, 2011). Protein and amino acid profiles have an important macronutrient that contributes to childhood growth and development. Children are more sensitive to nutrient deficiencies than adults because they have physiological function requirements that are fast enough for growth and development (Tessema et al., 2018). The low intake of nutrients protein is caused by wrong parenting, especially in providing complementary foods (Tampubolon and Karo-karo, 2014).

Therefore, the prevalence of stunting in Grobogan is still high and one of the factors is protein intake in children. Grobogan has local food freshwater fish Nile tilapia (Oreochromis niloticus) which has high nutrition content, especially protein and omega 3 . The researcher uses these source to increase the value of the product. It could be done by making fish protein hydrolysate (FPH). This study aimed to analyse the amino acid profile and the FPH of Nile tilapia.

\section{Materials and methods}

\subsection{Materials}

The Nile tilapia (Oreochromis niloticus) obtained from Grobogan Regency, Central Java Province, Indonesia. Fish were kept frozen and transported in a container with ice to be processed directly in a laboratory in Jakarta. In the laboratory, the fish was eviscerated and filleted before being hydrolysed or analysed for the amino acid.

\subsection{Hydrolysate processing}

Local protease enzyme was produced according to the modified result from previous research (Chasanah et al., 2019; Martosuyono et al., 2019). Bacteria from the Genus Bacillus play a role in industrial development. Bacillus licheniformis was used to produce microbial protease. The isolate was grown in Minimal Synthetic Medium (MSM) containing $0.7 \%\left(\mathrm{NH}_{4}\right)_{2} \mathrm{SO}_{4}, \quad 0.1 \%$ $\mathrm{K}_{2} \mathrm{HPO}_{4}, \quad 0.01 \% \quad \mathrm{MgSO}_{4}, \quad 0.1 \% \quad \mathrm{NaCl}, \quad 0.05 \%$ yeast extract, $1 \%$ skim milk or $0.6 \%$ technical grade skim milk, incubated at $37^{\circ} \mathrm{C} 125 \mathrm{rpm}$ for eighteen hrs. The supernatant was the crude enzyme. The optimum condition of bacterial fermentation and enzyme activity was taken from previous research (Zilda et al., 2013).

The fish hydrolysate was based on previous research (Chasanah et al., 2019; Martosuyono et al., 2019). Hydrolysis was performed in a $100 \mathrm{~L}$ steel jacketed vessel heated by hot water. The unit was equipped with a temperature reader and stirrer operated with a controlled electric motor. The temperature was controlled by adjusting the gas flow in the stove to maintain the temperature of a water jacket.

First, the meat of the Nile tilapia was chopped and blended with water (ratio $1: 1.5 \mathrm{w} / \mathrm{v}$ ), heated at $55^{\circ} \mathrm{C}$ and stirred at a rate of $70 \mathrm{rpm}$. Protease enzyme was added as such that the activity was 20.000 units $/ \mathrm{kg}$ substrate. Then, hydrolysed at $55^{\circ} \mathrm{C}$ for $7-8 \mathrm{hrs}$. The mixture was continuously stirred for $6 \mathrm{hrs}$ at $55^{\circ} \mathrm{C}$. After the optimized hydrolysis process time is achieved, the enzyme was inactivated at $90^{\circ} \mathrm{C}$ and held for 10 mins to stop the hydrolysis process. It will result in the filtration of the liquid and supernatant. Liquid FPH was obtained by centrifugation (if the amount is small) or by filtration using a 600-mesh membrane/filtering (Petrova et al., 2018). A total of $100 \mathrm{~kg}$ of fish yielded $40 \%$ of the filtrate $(40 \mathrm{~g})$. As much $40 \%$ of the filtrate is added $80 \mathrm{~L}$ of water, to about 100-120 L. Then, the liquid FPH was converted into powder using the spray dryer with maltodextrin as filler at a concentration of $20 \%(\mathrm{w} / \mathrm{v})$ (Chasanah et al., 2019; Martosuyono et al., 2019).

\subsection{Amino acid analysis}

The analysis of amino acids was analysed using an internal method developed by Saraswanti Indo Genetech laboratory (18-5-17/MU/SMM-SIG, UPLC). First, onepoint standardized concentration amino acids were created by adhering to internal standards. After that, 0.1$1 \mathrm{~g}$ of sample was weighed into the $20 \mathrm{~mL}$ vial headspace. Then, it is hydrolysed with $\mathrm{HCl}$ solution. 
Later, the resulting products were transferred into a 50 $\mathrm{mL}$ volumetric flask. Double distilled aquadest that have low mineral content was added until it is homogenised. After its homogen, the solution was filtered with a 0.2 $\mu \mathrm{m}$ syringe filter and collected. Next step was add the internal standard and proceed the solution to derivatization stage. Sample solution $(1 \mu \mathrm{m})$ was injected into the UPLC system. The condition to measure the sample used $\mathrm{C} 18$ column. The column temperature was maintained at $49^{\circ} \mathrm{C}$. Elueuen Accq., Tag ultra; aquadest for moving phase, gradient pump system, and photodiode array detector was include as the condition in this measurement.

\subsection{Statistical analysis}

Data analysis using the SPSS application with the Windows operating system. First, the data were tested for normality using Shapiro Wilk. Then, the data collected were analysed using paired t-test statistical test with a $95 \%$ confidence interval of the differences.

\section{Results and discussion}

Nile tilapia (Oreochromis niloticus) is a type of fish that has high economic value and is very popular with both the local and international communities. Nile tilapia is an important commodity in the world of freshwater fish business (Jim et al., 2017). Fish is a source of animal protein, a macronutrient that contains essential amino acids. Essential amino acids include lysine, methionine, threonine, tryptophan, isoleucine, leucine, phenylalanine, tyrosine, valine, histidine, and cysteine. Protein functions as growth, development, neurotransmitters, and as a source of energy (Nuss and Tanumihardjo, 2011). The fish protein content is rather high at about $15-24 \%$. In general, the five amino acids that are often deficient in children's diets were lysine, methionine, cysteine, threonine, tryptophan. Fish is rich in essential amino acids such as lysine, methionine, cystine, threonine, and tryptophan. Fish has a good source of lysine, which is very limited in cereals and nuts (Istiqomah et al., 2018). This is consistent with research in Africa showing that children who are at risk of stunting have problems on the sufficiency of essential amino acids such as tryptophan and lysine in diet.

In this study, the protein was processed into hydrolysate. Processing fish into protein hydrolysate aims to overcome fish damage and obtain food that is easily digested by the body because the protein has been broken down into amino acids and peptides. FPH has better functional properties than a fish meal because it has very high solubility and solubility does not change much even though it is treated at high temperatures, for example in the sterilization process it can survive in liquid form with high concentrations. It can serve as potential ingredients in a balanced human protein requirement, which can be absorbed by the body more quickly than intact proteins. After the hydrolysate processing, the highest result was the amino acid content of the Nile tilapia, namely L-leucine $(3200.33 \pm 14.64)$, LLysine (2987.33 \pm 23.54$)$ and L-Glutamic Acid (2582.67 \pm 35.39$)$. Nutrient content of the amino acid hydrolysate, namely L-Lysine (3372 \pm 81.18$)$, L-Glutamic Acid (2962.67 \pm 36.86$)$, and leusin $(2844.33 \pm 15.54)$.

Figure 1 shows the increased amino acid levels found in L-Glutamic Acid and L-Lysine. The average value of L-Glutamic Acid levels before the hydrolysate process is $2582 \mathrm{mg} / \mathrm{kg}$ and after hydrolysate is $2962 \mathrm{mg} /$ $\mathrm{kg}$. Glutamic acid is an essential amino acid that is useful for accelerating the healing of wounds in the intestine, improving mental health and reducing depression. If there was a deficiency it will negatively impact the integrity of the intestine and lead to immunosuppression. The average value of L-Lysine level before the hydrolysate is $2987 \mathrm{mg} / \mathrm{kg}$ and after hydrolysate is 3372 $\mathrm{mg} / \mathrm{kg}$. The amino acid lysine tends to influence the expression of Insulin Growth Factor-1 (IGF-1) which can promote growth (especially linear growth). Lysine can increase growth through increased synthesis and secretion of IGF-1 which can affect the growth of the Mammalian target of rapamycin (mTOR). mTORC11 signalling can determine the mass of cell size and can affect bone growth (Jing and Li, 2010).

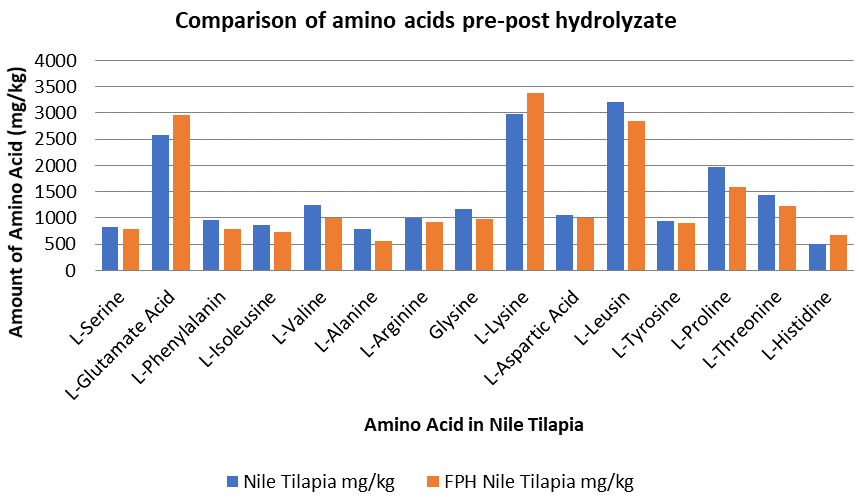

Figure 1. Comparison of amino acids of Nile tilapia (Prehydrolysate) and fish protein hydrolysate (FPH) of Nile tilapia (Post-hydrolysate)

The results indicated that the hydrolysis of Nile tilapia viscera led to an increase in protein content $(62.81 \pm 0.18 \%)$ (dry basis). Furthermore, the hydrolysis process also decreased the moisture content $(11.56 \pm 0.49 \%)$, fat content $(16 \pm 0.14 \%)$, and ash content $(5 \pm 0.17 \%)$ (dry basis). Glutamine had the highest amino acid level in hydrolysates (3.85 g/100 g), whereas cysteine had the lowest level $(0.32 \mathrm{~g} / 100 \mathrm{~g})$ (Riyadi et al., 2019). The chemical characteristics and amino acid 
Table 1. Amino acid content of Nile tilapia and FPH of Nile tilapia

\begin{tabular}{lcccc}
\hline \multicolumn{1}{c}{ Parameters } & $\begin{array}{c}\text { Nile tilapia } \\
\text { Mean } \pm \text { SD }\end{array}$ & $\begin{array}{c}\text { FPH } \\
\text { Mean } \pm \text { SD }\end{array}$ & t-values & P-values \\
\hline L-Serine & $835.67 \pm 16.50$ & $780.67 \pm 11.06$ & 7.328 & $0.018^{*}$ \\
L-Glutamate Acid & $2582.67 \pm 35.39$ & $2962.67 \pm 36.86$ & -40.897 & $0.001^{*}$ \\
L-Isoleusin & $870.67 \pm 7.64$ & $732.67 \pm 9.50$ & 31.659 & $0.001^{*}$ \\
L-Valine & $1248.67 \pm 28.57$ & $1002.33 \pm 10.50$ & 17.356 & $0.003^{*}$ \\
L-Alanine & $791.67 \pm 11.37$ & $567.33 \pm 17.21$ & 42.822 & $0.001^{*}$ \\
L-Arginine & $996 \pm 8.19$ & $923.3 \pm 6.66$ & 10.550 & $0.009^{*}$ \\
Glysine & $1173.67 \pm 4.16$ & $978.67 \pm 3.79$ & 43.244 & $0.001^{*}$ \\
L-Lysine & $2987.33 \pm 23.54$ & $3372 \pm 81.18$ & -6.427 & $0.023^{*}$ \\
L-Aspartic Acid & $1054.33 \pm 24.19$ & $1007.67 \pm 8.96$ & 2.455 & $0.134^{*}$ \\
L-Leusine & $3200.33 \pm 14.64$ & $2844.33 \pm 15.54$ & 20.474 & $0.002^{*}$ \\
L-Tyrosine & $944.67 \pm 23.19$ & $910 \pm 9.54$ & 3.512 & $0.072^{*}$ \\
L-Proline & $1973.33 \pm 10.69$ & $1598 \pm 35.16$ & 16.042 & $0.004^{*}$ \\
L.Threonin & $1430 \pm 22.52$ & $1224.67 \pm 7.23$ & 20.660 & $0.002^{*}$ \\
L-Histidine & $714.33 \pm 7.57$ & $676.33 \pm 12.86$ & 4.020 & $0.057^{*}$ \\
\hline
\end{tabular}

*Paired-t test

profile of Nile tilapia protein hydrolysates indicated a high nutritional value.

Table 1 shows the result of the analysis of the amino acid profiles in Nile tilapia before and after hydrolysate. The data was processed using a statistical analyst. First, the normality test of amino acid value data was carried out using the Shapiro Wilk test. The data obtained were normally distributed ( $p>0.05)$, and to show significance in the treatment group, followed by the paired t-test. The results of difference in the average value of L-aspartic acid are $(0.134>0.05)$, L-Tyrosine $(0.072>0.05)$ and LHistidine $(0.057>0.05)$ resulted in $p$-value $(p>0.05)$ means there is no significant difference between amino acids before hydrolysate (Nile tilapia) and after hydrolysate. For other amino acids the mean values ( $p$ $<0.05$ ) were significantly different in comparing the amino acids before hydrolysate (Nile tilapia) and after hydrolysate. The hydrolysate in this study produced was a high glutamic acid content which can be used as an alternative to food. Thus, the quality of children's food consumption could be fulfilled.

\section{Conclusion}

The average content of the amino acid profile of Nile tilapia before hydrolysate were L-leucine (3200.33 \pm 14.33$)$, L-lysine (2987.33 \pm 23.54$)$ and Lglutamic acid (2582.67 \pm 35.39$)$. The highest amino acid profile of the fish protein hydrolysate was L-lysine (3372 \pm 81.18$)$, L-glutamic acid $(2962.67 \pm 36.86)$ and Lleucine $(2844.33 \pm 15.54)$. The effect of hydrolysate increased the value of the amino acid profile of lysine and glutamic acid. The results of the statistical analysis showed significant differences in all levels of amino acid profiles $(p<0.05)$ except for 3 amino acids, namely Laspartic acid, L-tyrosine and L-histidine ( $\mathrm{p}>0.05)$.

\section{Conflict of interest}

The authors declare no conflict of interest.

\section{Acknowledgments}

The research work was funded by Diponegoro University through the Development and Application Research program in the 2020 fiscal year, contract no: $329-23 / \mathrm{UN} 7.6 .1 / \mathrm{PP} / 2020$.

\section{References}

Chasanah, E., Afifah D.N., Nuryanto., Fawzya, Y.N., Suryaningrum, T.D. and Martosuyono, P. (2018). Penggunaan HPI sebagai ingredient utama bubur instan untuk makanan pendamping air susu ibu (MPASI) untuk terapi gizi saluran cerna Jakarta, Indonesia: Balai besar riset pengolahan produk dan bioteknologi kelautan dan perikanan. [In Bahasa Indonesia].

Chasanah, E., Susilowati R., Yuwono, P., Zilda D.S. and Fawzya Y.N. (2019). Amino acid profile of biologically processed fish protein hydrolysate (FPH) using local enzyme to combat stunting. IOP Conference Series: Earth and Environmental Science, 278, 012013. https://doi.org/10.1088/17551315/278/1/012013

Dawood, M.A.O., Amer, A.A., Elbialy, Z.I. and Gouda, A.H. (2020). Effects of including triticale on growth performance, digestive enzyme activity, and growthrelated genes of Nile tilapia (Oreochromis niloticus). Aquaculture, 528, 735568. https://doi.org/10.1016/ j.aquaculture. 2020.735568

FAO (Food and Agriculture Organization). (2018). The State of World Fisheries and Aquaculture 2018 Meeting the sustainable development goals. Rome: FAO. 
Istiqomah, I., Nurrahman and Nurhidajah. (2018). Sifat Sensoris Tempe Kedelai Hitam Dengan Penambahan Kecambah dan Lama Inkubasi, Jurnal Pangan dan Gizi, 8(2), 70-81. [In Bahasa Indonesia].

Jim, F., Garamumhango, P. and Musara, C. (2017). Comparative Analysis of Nutritional Value of Oreochromis niloticus (Linnaeus), Nile tilapia, Meat from Three Different Ecosystems. Journal of Food Quality, 2017, $6714347 . \quad$ https:// doi.org/10.1155/2017/6714347

Jing, W.-Q. and Li, F.-C. (2010). Effects of Dietary Lysine on Growth Performance, Serum Concentrations of Insulin-Like Growth Factor-I (IGF -I) and IGF-I mRNA Expression in Growing Rabbits. Agricultural Sciences in China, 9(6), 887895. https://doi.org/10.1016/S1671-2927(09)60168-1

Magouz, F.I., Mahmoud, S.A., El-morsy, R.A.A., Ahamad, B., Soliman, A.A., Zaineldin, A.I. and Dawood, M.A.O. (2021). Dietary menthol essential oil enhanced the growth performance, digestive enzyme activity, immune-related genes, and resistance against acute ammonia exposure in Nile tilapia (Oreochromis niloticus). Aquaculture, 53, 2735944. https://doi.org/10.1016/ j.aquaculture.2020.735944

Martosuyono, P., Fawzya, Y.N., Patantis, G. and Sugiono. (2019). Enzymatic Production of Fish Protein Hydrolysates in A Pilot Plant Scale. Squalen Bulletin of Marine and Fisheries Postharvest Biotechnology, 14(2), 85-92. https:// doi.org/10.15578/squalen.v14i2.398

Ministry of Health Republic of Indonesia. (2018). Basic Health Research 2018. Jakarta, Indonesia: Ministry of Health Republic of Indonesia. Retrieved from: https://www.litbang.kemkes.go.id/

Nuss, E.T. and Tanumihardjo, S.A. (2011). Quality Protein Maize for Africa: Closing the Protein Inadequacy Gap in Vulnerable Populations. American Society for Nutrition, 2(3), 217-224. https://doi.org/10.3945/an.110.000182

Petrova, I., Tolstorebrov, I. and Magne, T. (2018). Production of fish protein hydrolysates step by step: technological aspects, equipment used, major energy costs and methods of their minimizing. International Aquatic Research, 10(3), 223-241. https:// doi.org/10.1007/s40071-018-0207-4

Riyadi P.H., Suprayitno E., Aulanni'am A. and Sulistiyati T.D. (2019) Chemical characteristics and amino acids profile of protein hydrolysates of Nile tilapia (Oreochromis niloticus) viscera. World's Veterinary Journal, 9(4), 324-328. https:// doi.org/10.36380/scil.2019.wvj41
Semba, R.D., Shardell, M., Sakr, F.A., Moaddel, R., Trehan, I., Maleta, K.M., Ordiz, M.I., Kraemer, K., Khadeer, M.A., Ferrucci, L. and Manary, M.J. (2016). Child Stunting is Associated with Low Circulating Essential Amino Acids. EbioMedicine, 6, 246-252. https://doi.org/10.1016/ j.ebiom.2016.02.030

Shokibi, A.N. (2015). The Relationship of Energy, Protein, Zinc and Physical Fitness Intake and Stunting Children Learning Achievement inSDN Penganten I, II and III, Klambu District, Grobogan Regency. Journal of Nutrition College, 4(1), 71-78. https://doi.org/10.14710/jnc.v4i1.8623

Tampubolon, N.L. and Karo-karo, T. (2014). Formulations of Instant Baby Porridge with Tempeh Flour and Pumpkin Flour Substitution as an Alternative Complementary Breast. Jurnal Rekayasa Pangan dan Pertanian, 2, 78-83.

Tessema, M., Gunaratna, N.S., Brouwer, I.D., Donato, K., Cohen, J.L., McConnell, M., Belachew, T., Belayneh, D. and Groote, H.D. (2018). Associations among High-Quality Protein and Energy Intake, Serum Transthyretin, Serum Amino Acids and Linear Growth of Children in Ethiopia. Multidisciplinary Digital Publishing Institute, 10, 1776. https://doi.org/10.3390/nu10111776

Uauy, R., Suri, D.J., Ghosh, S., Kurpad, A. and Rosenbergd, I.H. (2016). Low Circulating Amino Acids and Protein Quality: An Interesting Piece in the Puzzle of Early Childhood Stunting. EBioMedicine, 8, 28-29. https://doi.org/10.1016/ j.ebiom.2016.05.026

Zilda, D.S., Harmayani, E., Widada, J., Asmara, W., Irianto, H. E., Patantis, G. and Fawzya, Y.N. (2013). Screening of thermostable protease producing microorganisms isolated from Indonesian hot spring. Squalen Bulletin of Marine and Fisheries Postharvest Biotechnology, 7(3), 105-114. https:// doi.org/10.15578/squalen.v7i3.5 